\title{
The Effect of Back Massage on Decreasing Insomnia in the Elderly at the Posyandu Lansia Marsudi Waras Jebres Surakarta
}

\author{
Dita Mirawati $^{1 *}$, Juanda Izhar ${ }^{2}$, Lauria Shinta Oktivani ${ }^{3}$, \\ Wahyuni $^{4}$, Yudha Wahyu Putra ${ }^{5}$ \\ 1,2 Udayana University \\ 3,4 'Aisyiyah University of Surakarta \\ E-mail: ditamirawati20@gmail.com \\ https://doi.org/10.30787/gaster.v19i1.581
}

\section{ARTICLE INFO}

Keywords: Elderly; Insomnia;

Back Massage

\section{ABSTRACT}

Background; Along with increasing age in the elderly can cause various kinds of disorders, one of which is a disruption of sleep patterns (Insomnia). Sleep quality in most elderly people tends to change, some complain of difficulty in starting to sleep and go back to sleep when you wake up at night. Based on the results of a survey of 20 out of 50 elderly at the Posyandu Lansia Marsudi Waras have Insomnia disorder, most of them are caused by anxiety which can result not relaxing. To reduce insomnia in the elderly, one of them is by giving a back massage. Besides being able to reduce insomnia, back massage also has an effect on reducing anxiety because the emphasis on certain areas can stimulate dopamine hormone so that it decreases the mood. Objectives; This study aims to determine the effect of massage in reducing insomnia in the elderly. Methods; This study used a preexperimental method with a one group pre and post-test design research design. Sampling by random sampling. The number of samples in this study were 20 respondents. Results; The results of this study are significant $p=0,000(p<0.05)$, meaning that there is an effect of giving Back Massage to Decreasing Insomnia in the elderly. Conclusion; With these results it can be concluded that there is an effect of Back Massage on reducing Insomnia in the elderly. 


\section{BACKGROUND}

Elderly is the final stage of adulthood, so that the elderly is often referred to as late adulthood before entering the last period of human development, namely death, the elderly usually begins at the age of 65 years, which is marked by many changes in the lives of elderly individuals physically, cognitive and psychosocial. Based on these three changes, the change that is most felt and can be seen by other individuals is physical change, which is also known as the aging process (Azizah, 2011).

Old age is a continuation of adulthood which is a natural process that has been determined by God Almighty. Indonesia is one of the countries that is entering the age structure population because from year to year the number of Indonesians aged 60 years and over is increasing. Based on the results of the 2010 population census, it shows that the number of elderly people in Indonesia is 18.57 million people, an increase of about $7.93 \%$ from 2000 which was 14.44 million people. It is estimated that the number of elderly people in Indonesia will continue to increase by around 450,000 million people per year, so that by 2025 the number of elderly people in Indonesia will be around 34.22 million people (Badan Pusat Statistik, 2019).
The changes that occur in the elderly can cause various kinds of disorders, one of which is sleep disturbance (insomnia). With age, the quality of sleep in most elderly people tends to change, episodes of sleep with rapid eye movement or REM (Rapid eye movement) tend to shorten. There is a progressive decrease in the sleep stage with non-rapid eye movement (NREM). An elderly person who wakes up more often at night and needs more time to fall asleep. Insomnia is a condition that describes a person having difficulty sleeping. These conditions can include trouble sleeping, trouble sleeping, waking up frequently at night, and waking up too early. This condition results in a feeling of not being refreshed during the day and difficulties in carrying out daily activities and not fulfilling the need for good sleep (Respir, 2014).

Various efforts in the health sector that can be done to help the elderly who suffer from insomnia are pharmacological or non-pharmacological management. Pharmacologically, the management of insomnia is by giving drugs from the sedative-hypnotic class such as chlorate hydrate, etchlorvinol, flurazepam, triazolam. Pharmacological therapy has an immediate effect, but if it is given for a long time it can have harmful effects on the health of 
the elderly. Meanwhile, one of the nonpharmacological interventions for handling insomnia is complementary therapy (Potter \& Perry, 2015).

There are several complementary therapies to treat insomnia, namely: CBT (Cognitive Behaviour Therapy), Sleep Restriction Therapy, and Back massage. According to Kozier \& Berman (2010), back massage or effleurage is a type of massage consisting of long, soft, and flexible scrubbing movements. Research shows that back massage has the ability to generate relaxation responses. There are many benefits of back massage, namely increasing blood to tissues and organs, increasing the number of platelets, leucocytes, erythrocytes and hemoglobin without disturbing the acid-base balance, accelerating the recovery process of injured nerves and having a positive effect on cardiovascular parameters such as blood pressure, heart rate, and respiratory rate. and improve sleep quality.

The benefits of massage therapy (massage) can stimulate nerve points with finger pressure so that they can send signals directly to the brain to trigger the release of chemicals such as endorphins which can make you feel comfortable, reduce pain, and stress (Trionggo, 2013).. Massage can also repair joint problems, relax the body, relieve tension and relieve pain. In addition, to improve blood circulation, reduce anxiety and depression.

According to research conducted by Aziz (2013), which is a study to find the effect of massage therapy on insomnia levels in the elderly, from this study it was found that there was a significant effect between massage therapy on insomnia levels in the elderly.

Based on the results of a survey at the Posyandu Lansia Marsudi Waras Jebres Surakarta, there were a total of 20 elderly who experienced insomnia with different levels of insomnia, namely 12 elderly experiencing severe insomnia, 4 elderly experiencing very severe insomnia and 4 experiencing mild insomnia. Seeing the description above, the researchers are interested in further examining the effect of massage on reducing insomnia in the elderly.

Based on the above phenomena and problems, the researcher has carried out research on the effect of back massage on insomnia in the elderly at the Posyandu Lansia Marsudi Waras Jebres Surakarta.

\section{MATERIALS AND METHODS}

This research was conducted at Posyandu Marsudi Waras Jebres Surakarta. This type of 
research used pre-experiment with research design using pre and post-test design. The number of samples in this study amounted to 20 elderly who have sleep disorders according to the results of the screening in the sample. The sampling technique in this study used simple random sampling. The study was conducted for one month on subjects who met the study inclusion criteria.

The inclusion criteria in this study were: the subject had sleep disorders, the subject could understand the instructions given by the researcher, the subject was willing to become a research respondent by signing an informed consent. The exclusion criteria were: the subject was using a walking aid, and the subject was not healthy. Subjects are excluded (drop out) from the study if they suddenly experience illness while the research is in progress and the subject does not participate in the study a maximum of 2 times according to the scheduled time.

The 20 elderly will be given massage interventions 2 times a week with a duration of 30 minutes for each session.

The measurement of the level of insomnia in the elderly is used the Insomnia Rating Scale which will be carried out before the intervention (pre-test) and after the intervention (post-test).
Furthermore, the data obtained were processed and analyzed using SPSS software version 22 copyright from IBM Corporation in 2013. The normality test of the data used was using Saphiro Wilk and the effect test was processed using Wilcoxon because the data were not normally distributed.

\section{RESULTS AND DISCUSSION}

a. Characteristics of Respondents by Age

Table 1. Characteristics of Respondents by Age

\begin{tabular}{ccc}
\hline \multirow{2}{*}{ Age (in year) } & \multicolumn{2}{c}{ Respondent } \\
\cline { 2 - 3 } & (n) & $(\%)$ \\
\hline $68-65$ & 11 & $55 \%$ \\
$66-72$ & 9 & $45 \%$ \\
\hline Total & 20 & $100 \%$ \\
\hline
\end{tabular}

Based on Table 1, the age level of the most respondents is at the age of 58-65 years, because at that age many elderly experience insomnia. Complaints about sleep disorders will increase with age, the age factor is the most important factor affecting sleep quality, sleep efficiency (the amount of sleep time is compared to the time lying in bed) therefore, these factors can affect the quality of sleep in the elderly. 
The results of this study are in line with the theory of Nugroho (2015), which states that sleep disorders are the main complaint that is often experienced by the elderly, with an estimate of more than half of the elderly who are over 60 years of age experience difficulty sleeping and changes in sleep patterns with age such as architectural changes. sleep, night sleep is more easily disturbed, conditions of quality and duration are also disturbed, the elderly tend to have a greater desire to take a nap than young people. An elderly person often wakes up at night and takes a lot of time to fall asleep and during aging, sleep patterns undergo characteristic changes, which distinguishes young people from these changes including sleep fatigue, disturbed in the early morning, and increased number of naps and the amount of time spent sleeping deeper decreased.

\section{b. Characteristics Based on Gender}

Table 2. Characteristics of Respondents by Gender

\begin{tabular}{lcc}
\hline \multirow{2}{*}{ Sex } & \multicolumn{2}{c}{ Respondent } \\
\cline { 2 - 3 } & $(\mathrm{n})$ & $(\%)$ \\
\hline Female & 16 & $80 \%$ \\
Male & 4 & $20 \%$ \\
\hline Total & 20 & $100 \%$ \\
\hline
\end{tabular}

Judging from Table 2 shows that the majority of respondents who experience insomnia are women $(80 \%)$ than men $(20 \%)$. The greater number of women who experience insomnia proves that more insomnia is experienced by women or that gender affects the level of insomnia.

The results of this study are in accordance with the research of Khasanah \& Hidayati (2012), which states that 69 female respondents $(71.7 \%)$ of the total respondents experienced poor sleep quality. This shows that sleep quality is influenced by gender. Women have poor sleep quality due to a decrease in the hormones progesterone and estrogen which have receptors in the hypothalamus. These two hormones are hormones that have an important role in directly regulating circadian rhythm and sleep patterns. Decreasing estrogen hormone will also increase anxiety, anxiety and emotions are often uncontrolled, which can cause sleep disturbances.

According to Ko \& Lee (2014), anxiety and lifestyle are thought to be one of the factors causing insomnia, men have a lower level of anxiety than women and women are more anxious about their 
inability than men. Men are more active and explorative, while women are more sensitive.

c. Characteristics of Respondents by Occupation

Table 3. Characteristics of Respondents by Occupation

\begin{tabular}{ccc}
\hline \multirow{2}{*}{ Job } & \multicolumn{2}{c}{ Respondent } \\
\cline { 2 - 3 } & (n) & $(\%)$ \\
\hline Housewife & 12 & $60 \%$ \\
Factory workers & 5 & $25 \%$ \\
Employees & 3 & $15 \%$ \\
\hline
\end{tabular}

Most characteristics are housewife, namely 12 respondents. that the majority of respondents in the experimental group work as housewives with a total of 12 respondents with a percentage of $60 \%$ and a minority working as employees 3 respondents with a percentage of $15 \%$.

Elderly who are still actively working will quickly feel tired, tired and fatigued, which also makes it difficult for them to sleep because their bodies feel sick as a result of their work. Work is one of the sociocultural factors that can influence insomnia by working the possibility of individuals to access and understand information about health so that respondents have the knowledge to choose strategies in dealing with insomnia (Hanung, 2013). Housewife has a fairly high level of insomnia because housewife is a woman who manages the implementation of various kinds of household chores or a wife, a mother who only takes care of various jobs in the household (Ko \& Lee, 2014)

d. Characteristics of Respondents based on the pre and post Insomnia Rating Scale

Table 4. Measurement Value of Insomnia Rating Scale before Intervention (PreTest)

\begin{tabular}{ccc}
\hline \multirow{2}{*}{$\begin{array}{c}\text { Insomnia Rating Scale } \\
\text { Score }\end{array}$} & \multicolumn{2}{c}{ Pre-Test } \\
\cline { 2 - 3 } & (n) & $(\%)$ \\
\hline Ringan & 4 & $20 \%$ \\
Berat & 12 & $60 \%$ \\
Sangat Berat & 4 & $20 \%$ \\
\hline
\end{tabular}

Table 5. Measurement Value of the Insomnia Rating Scale after Intervention (Post-Test)

\begin{tabular}{ccc}
\hline Insomnia Rating & \multicolumn{2}{c}{ Post-Test } \\
\cline { 2 - 3 } Scale Score & $(\mathrm{n})$ & $(\%)$ \\
\hline Normal & 3 & $15 \%$ \\
Ringan & 12 & $60 \%$ \\
Berat & 5 & $25 \%$ \\
\hline
\end{tabular}


Judging from Table 4 and Table 5 after giving Back Massage, there are 5 elderly people who still experience severe insomnia, namely 5 elderly because the therapy process given to elderly people who suffer from insomnia is not long enough and maybe most of the elderly in the village do not control their sleep and dietary patterns. whose sleep patterns are poorly controlled can result in worsening sleep patterns and thus eating in the village there are still elderly people who experience severe insomnia even though they have been given therapy (Triyadini et al., 2010).

The measuring instrument used to measure insomnia is the Insomnia Rating Scale. This measuring tool measures insomnia problems in detail, for example problems with sleep disturbance, sleep duration, sleep quality and quality after waking.

\section{e. The Effect of Giving Massage on Insomnia}

Table 6. Analysis of Test the Effect of Giving Massage on Insomnia

\begin{tabular}{ccc}
\hline Wilcoxon & Asym.Sig & $\mathrm{Z}$ \\
\hline Pre Test-Post Test & $<0.000$ & -4.025 \\
\hline
\end{tabular}

Based on the results of the Wilcoxon test in the table, it is known that the data from pre and post-test Insomnia obtained significant results of $\mathrm{p}<0.001$, which means $\mathrm{p}$ less than 0.05 . meaning that there is a massage effect on the reduction of insomnia at the Posyandu for the Elderly Marsudi Waras Jebres Surakarta. So it can be concluded that giving massage has an effect on reducing insomnia. In this study, massage was given 2 times a week regularly for 3 weeks.

This research is the same as research conducted by Cinar \& Eser (2012), concerning the Effect on Sleep Quality of Back Massage in Older Adults in Rest Home in Izmir. The results showed that before back massage the $\mathrm{t}$ value was 4.78, while after back massage the $t$ value was 4.78 and the p-value was 0.000 . So that there is an effect of back massage on sleep quality in the elderly in a nursing home in Izmir, Turkey.

The same research was also carried out by Azis (2016), regarding the effect of lemongrass massage and aromatherapy on reducing insomnia in the elderly in nursing homes in the Surakarta area. The results obtained before the massage were the mean value was 16.13 , the $t$ 
value was 3,919 , after the massage the mean value was 11.73 , the $t$ value was 3,919 and the p-value was 0.001 . So that there is the effect of massage and aroma therapy of lemongrass on the reduction of insomnia in the elderly at the Dharma Bhakti Pajang Surakarta Home.

Another study was also conducted by Murti (2017), concerning the Effects of Circulo Massage on Sleep Disorders in Elderly Women at the Elderly Posyandu in Cebongan Ngestiharjo Kasihan Bantul. The result of this research is that the $t$ value is 12.688 and the $t$ value is 2.093 , and the $\mathrm{p}$ value is 0.000 . The results of this study indicate that there is a significant difference in the effect of circulo massage on sleep disorders in elderly women at the Elderly Posyandu Cebongan Ngestiharjo Kasihan Bantul.

Giving back massage can reduce insomnia because massage is a technique that can improve blood circulation, relax the body, relieve stress, relieve fatigue and fatigue so that it can improve sleep quality, by applying pressure at a certain point. When the muscle tissue contracts during massage, the nervous system in the surrounding area is compressed and the muscle tissue relaxes, the nerves will also be stretched, increasing parasympathetic activity to release neurotransmitters such as the hormone endorphine. Massage can release neurotransmitters such as endorphins, serotonin, acetylcholine, which can reduce the psychological effects of stress and provide a sense of comfort (Sharma 2009 dalam Ramadini $\&$ Putri, 2020).

Endorphine excretion results in increased endorphine levels. Increased levels of endorphine stimulate the production of the hormones dopamine and serotonin. The dopamine hormone will increase causing decreased anxiety, while the increased serotonin hormone can reduce sleep disorders. The massage mechanism to respond to nerve sensors then occurs vasodilation of blood and lymph vessels affecting blood flow to increase and blood circulation to become smooth (Aditya, 2013 in Ramadini $\&$ Putri, 2020). The activity of the parasympathetic nerves then signals the brain and bioelectrics throughout the body. Alpha waves will help a person's stress disappear and feel comfortable and relaxed (Guyton \& Hall, 2017).

Massage is a technique that can improve blood circulation, provide a 
feeling of relaxation to the body, relieve stress, relieve fatigue and fatigue so that it can improve sleep quality, by applying pressure at a certain point. When the muscle tissue contracts during massage, the nervous system around the massage area is also depressed and the muscle tissue relaxes, the nerves will also be stretched, thereby increasing parasympathetic activity to release neurotransmitters such as endorphins, serotonin, acetilcolin. Through the response generated by the brain, an increase in serotonin levels can reduce the psychological effects of stress and reduce psycho effects such as hypertension, the hormones released by the adrenal medulla on stress masses, namely norepineprine and epineprine released by the adrenal glands in the blood can increase the "fight and fight" response (Olney, 2005).

Giving this back massage will release adhesion fascia, improve visceral tissue that is experiencing dysfunction and has a sleep facilitation effect by secreting serotonin. This serotonin secretion will create a feeling of comfort and optimism, relaxation, feeling good, the ability to focus on concentration, and attention, the urge to eat. Adequate secretion of this hormone will control mood or mood, appetite and sleep. These effects such as comfort, relaxation, mood control and sleep in theory can improve sleep quality in the elderly (Jahdi et al., 2016).

As revealed by Potter \& Perry (2015), which states that a person will fall asleep when the person feels comfortable and relaxed. Conditions like this are the need for sleep for the elderly, so that the elderly do not have difficulty sleeping and can achieve deep sleep (NREM sleep stage 4) and an increase in sleep duration and efficiency in the elderly.

\section{CONCLUSIONS AND SUGGESTIONS}

Based on the results of the research that has been carried out, it can be concluded that giving back massage can significantly reduce insomnia levels using the Wilcoxon analysis on the elderly at the Posyandu Lansia Marsudi Waras Jebres in Surakarta.

Based on the results of the above research, it can be suggested for posyandu cadres to provide education and information to the public about the effect of giving back massage to reduce insomnia levels. For future researchers, it is expected to use the case and control groups or by increasing the number of the samples. 


\section{REFERENCE}

Azis, W. F. Al. (2016). Pengaruh Masase Kaki Dan Aromaterapi Sereh Terhadap Penurunan Insomnia Pada Lansia Di Panti Wredha Daerah Surakarta. Naskah Publikasi.

Aziz, M. T. (2013). Pengaruh Terapi Pijat (Massage) Terhadap Tingkat Insomnia Pada Lansia Di Unit Rehabilitasi Sosial Pucang Gading Semarang. Jurnal Keperawatan.

Azizah, L. M. (2011). Keperawatan Lanjut Usia. Yogyakarta: Graha Ilmu.

Badan Pusat Statistik. (2019). Statistik Penduduk Lanjut Usia di Indonesia 2019. Badan Pusat Statistik: Jakarta.

Cinar, Ş., \& Eser, I. (2012). Effect on Sleep Quality of Massage Effect on Sleep Quality of Back Massage in Older Adults in Rest Home*. Dokuz Eylül Üniversitesi Hemşirelik Yüksekokulu Elektronik Dergisi. 5(1):2-7.

Guyton, A. C., \& Hall, J. E. (2017). Buku Ajar Fisiologi Kedokteran. In Elsevier: Singapore.

Jahdi, F., Mehrabadi, M., Mortazavi, F., \& Haghani, H. (2016). The effect of slowstroke back message on the anxiety levels of Iranian women on the first postpartum day. Iranian Red Crescent Medical Journal. 18(8):1-9 https://doi. org/10.5812/ircmj.34270

Hanung, N. (2013). Pengaruh Pekerjaan Ibu Rumah Tangga terhadap Kualitas Tidur pada Ibu-ibu di Desa Ngestiharjo Kasihan Bantul Yogyakarta. Skripsi. Program Studi S1 Fakultas Ilmu Kesehatan Universitas 'Aiayiyah Yogyakarta.

Khasanah, K., \& Hidayati, W. (2012). Kualitas Tidur Lansia Balai Rehabilitasi Sosial “MANDIRI” Semarang. Jurnal Nursing Studies. 1(1): 189-196. http:// ejournal-s1.undip.ac.id/index.php/ jnursing

Ko, Y. L., \& Lee, H. J. (2014). Randomised controlled trial of the effectiveness of using back massage to improve sleep quality among Taiwanese insomnia postpartumwomen. Midwifery. 30(1): 60-64 https://doi.org/10.1016/j. midw.2012.11.005

Kozier, B., \& Berman, S. (2010). Buku Ajar Fundamental Keperawatan: Konsep. In Proses, dan Praktik, Jakarta: EGC.

Murti, N. W. (2017). Efek Circulo Massage Terhadap Gangguan Tidur Pada 
Wanita Lansia Di Posyandu Lansia Cebongan Ngestiharjo Kasihan Bantul. VI(3), 1-9.

Nugroho, M. B. (2015). Keperawatan Gerontik. In Journal of Chemical Information and Modeling.

Olney, C. M. (2005). The effect of therapeutic back massage in hypertensive persons: A preliminary study. Biological Research for Nursing. 7(2): 98-105. https://doi. org/10.1177/1099800405280827

Potter, P. A., \& Perry, A. G. (2015). Fundamental Keperawatan Buku 1 Ed. 7. In Jakarta: Salemba Medika.

Ramadini, I., \& Putri, J. (2020). Pengaruh Back Massage Terhadap Insomnia Pada Lansia di Panti Sosial Tresna Werdha (PSTW) Sabai Nan Aluih
Sicincin Tahun 2018. Jurnal Amanah Kesehatan. 2(1): 44-55.

Respir Matthew. (2014). Insomnia. American Thoracic Society, 190, 9-10.

Setyawan, Riko. (2017). Pengaruh Pemberian Massage Punggung dan Senam Lansia Terhadap Kualitas Tidur pada Lansia. Naskah Publikasi. Program Studi S1 Fisioterapi Fakultas Ilmu Kesehatan Universitas 'Aisyiyah Yogyakarta.

Trionggo, I. (2013). Panduan Sehat Sembuhkan Penyakit dengan Pijat \& Herbal (1st ed.). Yogyakarta: Indoliterasi.

Triyadini. (2010). Efektifitas Terapi Massage dengan Terapi Mandi Air Hangat Terhadap Penurunan Insomnia Lansia. Jurnal Kesehatan Keperawatan (3)5: 174-181. 